\title{
RETURN TO PLAY AFTER HEALTH COMPLICATIONS ASSOCIATED WITH INFECTIOUS MONONUCLEOSIS GUIDED ON AUTONOMIC NERVOUS SYSTEM ACTIVITY IN ELITE ATHLETE: A CASE STUDY
}

\author{
Michal Botek, Pavel Stejskal, Jaroslav Větvička*
}

\author{
Faculty of Physical Culture, Palacký University, Olomouc, Czech Republic \\ * Czech Medical Olympic Centre, Prague, Czech Republic
}

Submitted in January, 2012

BACKGROUND: Infectious mononucleosis (IM) is an acute serious illness which requires among other things an interruption of training. The return to play for athletes after IM is complicated and a long-term process which could result in the relapse of health complications linked fundamentally with the illness.

OBJECTIVE: The aim of this study was to design a convalescence program which leads to an improvement in physical fitness and provides a safe return to play without relapse of health complications for an elite athlete who suffered from IM.

METHODS: The convalescence program lasted almost 3 months. Training load was optimized based on autonomic nervous system (ANS) activity which was assessed by spectral analysis (SA) of heart rate variability (HRV). There were evaluated an individual spectral variables - very low frequency power $\left(\mathrm{P}_{\mathrm{VLF}}\right)(0.02-0.05 \mathrm{~Hz})$; low frequency power $\left(\mathrm{P}_{\mathrm{LF}}\right)(0.05-0.15 \mathrm{~Hz})$, high frequency power $\left(\mathrm{P}_{\mathrm{HF}}\right)(0.15-0.50 \mathrm{~Hz})$, total power $\left(\mathrm{P}_{\mathrm{T}}\right)(0.02-0.50 \mathrm{~Hz})$, ratio $\mathrm{P}_{\mathrm{VLF}} / \mathrm{P}_{\mathrm{HF}}$ and $\mathrm{P}_{\mathrm{LF}} / \mathrm{P}_{\mathrm{HF}}$; heart rate (HR), and age-dependent complex index of SA HRV - index of vagal activity, sympathovagal balance, and total score. Further, perceived exertion during exercise and morning fatigue was assessed. Repeated biochemical analysis was focused on the selected transaminase level.

RESULTS: Among recovery periods, an increase in mean of $\mathrm{P}_{\mathrm{T}}$ was accompanied by elevation of $\mathrm{P}_{\mathrm{VLF}} / \mathrm{P}_{\mathrm{HF}}$ and $\mathrm{P}_{\mathrm{LF}} / \mathrm{P}_{\mathrm{HF}}$. No significant differences in mean values of any complex index of SA HRV among periods were found. A decline in HR was identified during measurements in lying, but mostly in supine. A significant elevation of perceived exertion during exercise occurred between periods. The morning fatigue culminated during the last period. No relationship between subjective feeling of fatigue and complex index of SA HRV was found.

CONCLUSIONS: A convalescence strategy based on assessment of ANS activity brought an improvement in physical fitness, in spite of borderline or mild elevated transaminase level. We suggest that a combination of both noninvasive SA HRV and periodic assessment of biochemical indicators of liver state seems to be a promising strategy for determination of safe application of training load during convalescence after IM.

Keywords: Heart rate variability, fatigue, hepatitis, Epstein-Barr virus, detraining, convalescence.

\section{INTRODUCTION}

Infectious mononucleosis (IM) is a disease caused the Epstein-Barr virus which afflicts many athletes each year (Putukian et al., 2008). A conservative way of treatment IM is commonly accompanied by the advice of the restriction of contact sport (Papesch \& Watkins, 2001) and/or intestive physical activity and e.g. the diet (Candy, Chalder, Cleare, Wessely, \& Hotopf, 2005). However, athletes often rush the return to training and competition participation, and thus risk a relapse of health complications linked with fundamental disease. In literature, there is still a lack of information or ambiguous recommendations how to manage convalescence after IM in term of the suitable start or optimal intensity of exercise. Some authors recommended beginning with low physical activity after two week (Welch
\& Wheeler, 1986), but also after 8 weeks (Moolenar, Peters, \& Bolk, 1988). The consensus from more current literature is that light noncontact activities may commence 3 weeks from symptom onset, but the returning to contact activities is more complicated (Putukian et al., 2008). Moreover, from review of Waninger and Harcke (2005) results that no strong evidence-based information supports use of a single parameter to predict the safe return to sport participation.

Spectral analysis of heart rate variability (SA HRV) is a non-invasive method which enables quantification of autonomic nervous system (ANS) activity which is accepted as sensitive marker of homeostatic disturbances (Aubert, Seps, \& Beckert, 2003). It well documented that IM is associated with the prolonged fatigue (Katz, Shiraishi, Mears, Binns, \& Tailor, 2009; Rea, Russo, Katon, Ashley, \& Buchwald, 2001) that causes an im- 
pairment in ANS activity in terms of the reduction in vagal activity and the shift of sympathovagal balance towards sympathetic predominance (Wyller, Barbieri, Thaulow, \& Saul, 2008). Impairment in autonomic regulation may induce a decrease in adaptation capacity of athlete that delays a convalescence process. On the other hand, higher ANS activity is linked with better homeostasis regulation which could positively affect physical performance (Pichot et al., 2002).

The main purpose of this study was to design a convalescence program for elite athlete after IM which was based on the maintaining ANS activity in balance via optimization of training intensity using SA HRV.

\section{METHODS}

\section{Participants}

One elite Czech basketball player after IM volunteered to participate in the present study. He was a non-smoker and during the study he did not use any medication which may affect ANS. Characteristics of the athlete is presented in TABLE 1.

\section{Time frame of health complication and subsequent treatment}

An acute cytomegalovirus accompanied with elevation of transaminase level was identified in our subject in January 2010. Athlete underwent a standard treatment (a strictly diet with rest on bed) lasting two months which resulted in an improvement in health status. Thus, he decided for the return to play. Unfortunately, deterioration in health complication associated with the fundamental disease occurred after one month from the return to competition again. The relapse caused another interruption of sport participation including physical activities for next two months when he was still highly fatigued, and frequently suffered by infection of the upper respiratory tract.

Approximately in half of August 2010 began the convalescence program which lasted to the end of the September 2010. Athlete returned for the first time to competition in the $6^{\text {th }}$ of September, and during next month he fully participated in the basketball training and competitions. Particular parts of developed program including both the exercise intensity, and training drills are clearly presented in TABLE 2 . During convalescence period athlete repeatedly underwent analysis of alanine amino transferase (ALT) level; aspartat amino transferase (AST) level, and gama glutamyl transferase (GGT) level (TABLE 5).

\section{Experimental design}

Before the study started, the participant was closely informed about the study design, and then he submitted written informed consent. Further, athlete underwent preliminary measurements in order to preclude any medical or health limitations to performing the maximal exertion test. Before performing of maximal stress test, athlete underwent basic anthropological measurement

\section{TABLE 1}

Basic morphological a physiological characteristics

\begin{tabular}{|c|c|c|c|c|c|c|c|c|}
\hline $\begin{array}{c}\text { Parameter } \\
\text { [unit] }\end{array}$ & $\begin{array}{c}\text { Age } \\
\text { [year] }\end{array}$ & $\begin{array}{c}\text { BMI } \\
{\left[\mathrm{kg} \cdot \mathrm{m}^{-2}\right]}\end{array}$ & $\begin{array}{c}\text { Body Fat } \\
{[\%]}\end{array}$ & $\begin{array}{l}\text { HRrest } \\
\text { [BPM] } \\
\end{array}$ & $\begin{array}{c}\text { HRmax } \\
\text { [BPM] }\end{array}$ & 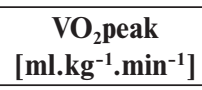 & $\begin{array}{c}\text { MPO } \\
{\left[\mathrm{W} \cdot \mathrm{kg}^{-1}\right]}\end{array}$ & $\begin{array}{c}\text { BP } \\
\text { [torr] }\end{array}$ \\
\hline Pre-test & 28 & 21.73 & 9.1 & 65 & $180 *$ & $36.8 *$ & $3.4^{*}$ & $128 / 72$ \\
\hline Post-test & 28 & 22.01 & 7.6 & 53 & 177 & 61.1 & 7.0 & $124 / 79$ \\
\hline
\end{tabular}

Legend: HRrest - resting heart rate, $\mathrm{HRmax}$ - maximal heart rate, BPM - beat per minute, BP - blood pressure, $\mathrm{VO}_{2}$ peak - peak oxygen uptake, BMI - Body Mass Index, MPO - maximal power output, percentage of body fat was computed from 10 skin fold caliper testing according to Pařízková (1962), * value was achieved during measurement on bicycle

TABLE 2

Characteristics of physical activities and mean exercise intensity during recovery period

\begin{tabular}{|l|c|c|c|}
\hline Convalescence & $\mathbf{1}^{\text {st }}$ phase & $\mathbf{2}^{\text {nd }}$ phase & $\mathbf{3}^{\text {rd }}$ phase \\
\hline HR [BPM] & $110-125$ & $125-145$ & $145-175$ \\
\hline HRmax [\%] & $61-66$ & $66-77$ & $60-90(120)$ \\
\hline Duration [min.] & $10-20$ & $30-50$ & 67 \\
\hline Physical activity & $\begin{array}{l}\text { Walking (uphill-downhill), } \\
\text { swimming, cycling on stationary } \\
\text { bicycle, rowing on simulator, easy } \\
\text { work out with own body. }\end{array}$ & $\begin{array}{l}\text { Jogging, swimming, cycling, rowing } \\
\text { on simulator, moderate work out } \\
\text { with own body, athletics training. }\end{array}$ & $\begin{array}{l}\text { Running, work out, swimming, } \\
\text { basketball drills, athletics training, } \\
\text { circle resistant training. }\end{array}$ \\
\hline
\end{tabular}

Legend: HR - heart rate, BPM - beat per minute, HRmax - maximal heart rate, \% - percentage, min. - minute 
and monitoring of resting ANS activity. All measurements were performed between 8 to 10 a.m. Athlete was required to avoid eating and drinking any substance affecting ANS activity for minimally 2 hours before the ANS measurement.

Pre-convalescence maximal stress test was performed on a bicycle ergometer Ergoline 900 in order to establish the peak oxygen uptake $\left(\mathrm{VO}_{2}\right.$ peak $)$ and maximal heart rate (HRmax). Ventilation and gas exchange were continually analyzed (Oxycon 4, Mijnhardt Holland) during the exercise and were reported as mean for $30 \mathrm{~s}$. Post convalescence maximal stress test was performed on a treadmill (Lode Valliant, Netherlands). Ventilation and gas exchange were continually analyzed (ZAN 600 Ergo USB, Germany) during the exercise and were reported as mean for $30 \mathrm{~s}$. HR responses were monitored (S810 Polar, Finland) continuously during both maximal exercise tests.

ANS activity was measured by the athlete himself after properly training each day in the morning. Electrocardiographic data were continually sampled in a quiet room during a standardized ortho-clinostatic maneuver of lying-standing-lying by system VarCor PF 7 (Salinger \& Gwozdziewicz, 2008) which requests for shortterm spectral analysis of HRV both $300 \mathrm{R}-\mathrm{R}$ intervals and 300 seconds per position. Frequency domain analyses were performed according to the methods described by Salinger et al. (1998). Amplitude density of the collected signal was estimated using the fast Fourier transform method with a partly modified Coarse-Graining Spectral Analyze algorithm (Yamamoto \& Hughson, 1991). Power of mean spectral components were calculated by integrating area under the power spectral density curve in the frequency ranges according to Salinger et al. (1998) - power very low frequency $\left(\mathrm{P}_{\mathrm{VLF}}\right)$ 0.02-0.05 $\mathrm{Hz}$; power low frequency $\left(\mathrm{P}_{\mathrm{LF}}\right) 0.05-0.15 \mathrm{~Hz}$, power high frequency $\left(\mathrm{P}_{\mathrm{HF}}\right) 0.15-0.5 \mathrm{~Hz}$, and total power $\left(\mathrm{P}_{\mathrm{T}}\right)$ $0.02-0.5 \mathrm{~Hz}$, respectively. Resting heart rate (HRrest) was computed as a mean for $5 \mathrm{~min}$. in second lying position. The autonomic cardiac activity was also expressed by complex indexes of SA HRV (Stejskal et al., 2002) the complex index of the vagal activity (VA), the complex index of the sympathovagal balance (SVB) and the complex index of the total score (TS). Parameter function age (FA) represents the value of TS which was adjusted into the age. The reference values of SA HRV indexes range from -5.0 to +5.0 points. The physiological values have been established for both VA and SVB in range from -2.0 to +2.0 points; for TS from -1.5 to +1.5 points (Stejskal, Přikryl, \& Jakubec, 2004).

The aim of the optimizing process was to keep the ANS activity in balance and throughout avoiding longterm reduction in ANS activity due to excess training load. The process starts automatically when the subject finished at least the fifth measurements of ANS activity. Optimizing procedure is based on comparing a magnitude of differences between ANS activity in actual measurement with the mean of ANS activity at least five and maximally twenty previous measurements. In this case, autonomic activity is represented by FA. The tested subject received one of the four possible recommendations - an increase in intensity; preserved actual intensity; reduce intensity and/or temporally interrupt the training. The whole procedure is detailed described in study of Šlachta, Stejskal, and Elfmark (2003).

In all training sessions, HR was controlled by HR Polar 810 monitor (Finland). Immediately after training sessions was evaluated perceived exertion on the 16 points Borg scale. The athlete further assessed the feeling of fatigue each time before the ANS activity measurement. The level of subjective feeling of fatigue ranged from 0 (no fatigue) to 5 (extremely high) point(s). This scale was established only for this project, therefore it was not validated.

\section{Statistical analysis}

Data were analysed using software STATISTICA 9.0. The normal Gaussian distribution of the analysed data was verified by the Kolmogorov-Smirnov test. Values of HR, fatigue, and perceived exertion were tested using one-way repeated-measures of ANOVA with Fischer LSD post hoc test. Kruskal-Wallis $H$-test followed by Wilcoxon test (post hoc analysis) was conducted to examine the effect of exercise on complex index of SA HRV. Relationship between selected variables was analyzed by Pearson correlation. In all analysis, $p \leq .05$ was considered to be statistically significant.

\section{RESULTS}

TABLE 3 shows that a significant increase in mean $\mathrm{P}_{\mathrm{VLF}}, \mathrm{P}_{\mathrm{LF}}, \mathrm{P}_{\mathrm{HF}}, \mathrm{P}_{\mathrm{T}}$ and ratio $\mathrm{P}_{\mathrm{VLF}} / \mathrm{P}_{\mathrm{HF}}$ was found in the $2^{\text {nd }}$ and the $3^{\text {rd }}$ period compared to the $1^{\text {st }}$ period in standing position. The mean $\mathrm{P}_{\mathrm{LF}}$ and $\mathrm{P}_{\mathrm{T}}$ significantly increased in the $3^{\text {rd }}$ compared to $2^{\text {nd }}$ period in standing. Mean HR in standing position decreased significantly among periods. In lying position, only $\mathrm{P}_{\mathrm{VLF}}$ and ratio $\mathrm{P}_{\mathrm{VLF}} / \mathrm{P}_{\mathrm{HF}}$ significantly increased in the $2^{\text {nd }}$ compared to the $1^{\text {st }}$ period. The mean $\mathrm{P}_{\mathrm{VLF}}, \mathrm{P}_{\mathrm{LF}}, \mathrm{P}_{\mathrm{T}}$ and ratio $\mathrm{P}_{\mathrm{VLF}} / \mathrm{P}_{\mathrm{HF}}$ and $\mathrm{P}_{\mathrm{LF}} / \mathrm{P}_{\mathrm{HF}}$ significantly increased in the $3^{\text {rd }}$ period compared to the $1^{\text {st }}$ period. The ratio $\mathrm{P}_{\mathrm{LF}} / \mathrm{P}_{\mathrm{HF}}$ significantly increased also in the $3^{\text {rd }}$ period compared to $2^{\text {nd }}$ period. A significant reduction in mean HR in lying position was investigated only in the last period compared to both previous periods.

TABLE 4 shows that statistical analysis did not find any significant differences in mean values of complex index of SA HRV among periods. A significant increase in mean value of perceived exertion occurred between subsequent periods. The mean value of perceived fatigue was significantly higher only in the $3^{\text {rd }}$ period compared to the $1^{\text {st }}$ period (TABLE 4). 
TABLE 3

Statistical analysis of individual variables of SA HRV during convalescence periods

\begin{tabular}{|c|c|c|c|}
\hline Parameter [unit] & $\begin{array}{c}1^{\text {st }} \text { period } \\
\mathrm{N}=29\end{array}$ & $\begin{array}{c}2^{\text {nd }} \text { period } \\
\mathrm{N}=29\end{array}$ & $\begin{array}{c}3^{\text {rd }} \text { period } \\
N=29\end{array}$ \\
\hline $\mathbf{S}_{-} \mathbf{P}_{\mathrm{VLF}}\left[\mathrm{ms}^{2}\right]$ & $60.57 \pm 64.06$ & $186.98 \pm 102.85^{*}$ & $256.28 \pm 152.53 \dagger$ \\
\hline $\mathbf{S}_{-} \mathbf{P}_{\mathrm{LF}}\left[\mathrm{ms}^{2}\right]$ & $233.99 \pm 150.72$ & $353.34 \pm 159.15^{*}$ & $531.50 \pm 221.62 \dagger \S$ \\
\hline $\mathbf{S}_{-} \mathbf{P}_{\mathrm{HF}}\left[\mathrm{ms}^{2}\right]$ & $19.09 \pm 12.65$ & $31.97 \pm 17.14 *$ & $49.21 \pm 31.96 \dagger$ \\
\hline $\mathbf{S}_{-} \mathbf{P}_{\mathrm{VLF}} / \mathbf{P}_{\mathrm{HF}}$ & $3.62 \pm 3.56$ & $7.91 \pm 7.36^{*}$ & $6.24 \pm 4.62 \dagger$ \\
\hline $\mathbf{S}_{-} \mathbf{P}_{\mathrm{LF}} / \mathbf{P}_{\mathrm{HF}}$ & $13.38 \pm 5.01$ & $13.49 \pm 7.79 \mathrm{NS}$ & $13.46 \pm 6.85 \mathrm{NS}$ \\
\hline $\mathbf{S}_{-} \mathbf{P}_{\mathrm{T}}\left[\mathrm{ms}^{2}\right]$ & $313.66 \pm 206.97$ & $572.28 \pm 220.31^{*}$ & $836.99 \pm 329.98 \dagger \S$ \\
\hline S_HR [BPM] & $97.59 \pm 7.16$ & $84.11 \pm 2.82 *$ & $79.19 \pm 5.99 \dagger \S$ \\
\hline $\mathbf{L}_{-} \mathbf{P}_{\mathrm{VLF}}\left[\mathrm{ms}^{2}\right]$ & $310.02 \pm 226.19$ & $439.67 \pm 275.00^{*}$ & $618.33 \pm 428.00 \dagger$ \\
\hline $\mathbf{L}_{-} \mathbf{P}_{\mathrm{LF}}\left[\mathrm{ms}^{2}\right]$ & $392.17 \pm 242.73$ & $480.77 \pm 268.89 \mathrm{NS}$ & $939.86 \pm 572.20 \dagger \S$ \\
\hline $\mathbf{L}_{-} \mathbf{P}_{\mathrm{HF}}\left[\mathrm{ms}^{2}\right]$ & $4,125.09 \pm 1,371.29$ & $4,389.80 \pm 1,272.23 \mathrm{NS}$ & $3,966.05 \pm 1,252.93 \mathrm{NS}$ \\
\hline $\mathbf{L}_{-} \mathbf{P}_{\mathrm{VLF}} / \mathbf{P}_{\mathrm{HF}}$ & $0.08 \pm 0.07$ & $0.11 \pm 0.06^{*}$ & $0.16 \pm 0.10 \dagger$ \\
\hline $\mathbf{L}_{-} \mathbf{P}_{\mathrm{LF}} / \mathbf{P}_{\mathrm{HF}}$ & $0.11 \pm 0.08$ & $0.12 \pm 0.08 \mathrm{NS}$ & $0.25 \pm 0.16 \dagger \S$ \\
\hline $\mathbf{L} \_\mathbf{P}_{\mathrm{T}}\left[\mathrm{ms}^{2}\right]$ & $12,920.14 \pm 4,248.69$ & $14,095.80 \pm 3,865.08 \mathrm{NS}$ & $16,731.56 \pm 5,620.09 \dagger$ \\
\hline L_HR [BPM] & $51.18 \pm 4.13$ & $50.22 \pm 2.52 \mathrm{NS}$ & $48.11 \pm 4.06 \dagger \S$ \\
\hline
\end{tabular}

Legend: $\mathrm{S}$-standing position, $\mathrm{L}$ - lying position, $\mathrm{P}_{\mathrm{VLF}}$ - power very low frequency, $\mathrm{P}_{\mathrm{LF}}$ - power low frequency, $\mathrm{P}_{\mathrm{HF}}-$ power high frequency, $\mathrm{P}_{\mathrm{T}}$ - total power, HR - heart rate, ${ }^{*}-1^{\text {st }}$ period vs $2^{\text {nd }}$ period, $\dagger-1^{\text {st }}$ period vs $3^{\text {rd }}$ period, $\S-2^{\text {st }}$ period vs $3^{\text {rd }}$ period (Kruskal-Wallis $H$-test followed by Wilcoxon test), $P \leq .05$, NS - non significant, values are given as mean $\pm \mathrm{SE}$

\section{TABLE 4}

Statistical analysis of investigated parameters during different convalescence period

\begin{tabular}{|l|c|c|c|}
\hline \multicolumn{1}{|c|}{ Parameter [unit] } & $\begin{array}{c}\mathbf{1}^{\text {st }} \text { period } \\
\mathbf{N = 2 9}\end{array}$ & $\begin{array}{c}\mathbf{2}^{\text {nd }} \text { period } \\
\mathbf{N = 2 9}\end{array}$ & $\begin{array}{c}3^{\text {rd }} \text { period } \\
\mathbf{N}=\mathbf{2 9}\end{array}$ \\
\hline TS [points] & $0.83 \pm 0.54$ & $0.98 \pm 0.44 \mathrm{NS}$ & $0.86 \pm 0.55 \mathrm{NS}$ \\
\hline VA [points] & $0.52 \pm 0.51$ & $0.67 \pm 0.38 \mathrm{NS}$ & $0.62 \pm 0.53 \mathrm{NS}$ \\
\hline SVB [points] & $1.40 \pm 0.85$ & $1.57 \pm 0.84 \mathrm{NS}$ & $1.31 \pm 0.97 \mathrm{NS}$ \\
\hline Borg scale [points] & $11.12 \pm 2.71$ & $13.31 \pm 2.29 *$ & $14.69 \pm 2.16 \dagger \S$ \\
\hline Fatigue [points] & $1.38 \pm 0.94$ & $1.59 \pm 0.98 \mathrm{NS}$ & $2.10 \pm 1.01 \dagger$ \\
\hline
\end{tabular}

Legend: TS - complex index of total score, VA - complex index of vagal activity, SVB - complex index of sympathovagal balance, $P \leq .05$ (Kruskal-Wallis $H$-test followed by Wilcoxon test), NS - non significant, * $-1^{\text {st }}$ period vs $2^{\text {nd }}$ period, $\dagger-1^{\text {st }}$ period vs $3^{\text {rd }}$ period, $\S-2^{\text {st }}$ period vs $3^{\text {rd }}$ period (ANOVA; Fischer LSD post hoc test), $P \leq .05$, NS - non significant, values are given as mean \pm SE

\section{TABLE 5}

Results of transaminase levels analysis during convalescence and after 3 months

\begin{tabular}{|l|c|c|c|c|c|c|c|}
\hline $\begin{array}{l}\text { Marker [unit] } \\
\text { (RV) }\end{array}$ & 19.7 .2011 & 10.8. & 17.8. & 1.9. & 3.10. & 4.12. & 28.3 .2012 \\
\hline $\begin{array}{l}\text { ALT [ukat L } \\
(\mathbf{0 . 1 5}-\mathbf{0 . 7 3 )}\end{array}$ & 1.10 & 0.83 & 0.76 & 0.83 & 1.35 & 1.21 & 0.76 \\
\hline $\begin{array}{l}\text { AST [ukat L } \\
(\mathbf{0 . 0 4 - 0 . 6 6 )}\end{array}$ & 0.59 & 0.55 & 0.44 & 0.50 & 0.64 & 0.76 & 0.50 \\
\hline $\begin{array}{l}\text { GGT [ukat L-1 } \\
(\mathbf{0 . 1 4 - 0 . 8 4 )}\end{array}$ & 0.79 & 0.68 & 0.64 & 0.75 & 0.76 & 0.72 & 0.64 \\
\hline
\end{tabular}

Legend: RV - reference value, ALT - alanine amino transferase, AST - aspartat amino transferase, GGT - gama glutamyl transferase, $\mathrm{RV}$ - reference values 


\section{TABLE 6}

Results of Pearson correlation analysis between selected variables $(\mathrm{N}=87)$

\begin{tabular}{|l|c|c|c|}
\hline $\mathbf{r}_{\mathbf{p}}$ & TS & VA & SVB \\
\hline Perceived Fatigue & -0.054 & 0.060 & -0.154 \\
\hline
\end{tabular}

Legend: TS - complex index of total score, VA - complex index of vagal activity, SVB - complex index of sympatovagal balance, $r_{p}-$ Pearson correlation

TABLE 5 shows that the values of ALT were classified as slightly elevated, AST as normal (except for one investigation). All values of GTT were indentified in normal range. An improvement in all parameters occurred after three moths of return to standard training exercise. No relationship between any complex index of SA HRV and morning fatigue was found.

\section{DISCUSSION}

The aim of this study was to design a convalescence program for elite athlete after IM which contributes to an improvement of his fitness level and with the safe return to play without relapse of the fundamental disease. Our strategy was based on the optimizing of training load according to the ANS activity by using SA HRV.

The analysis revealed an increase in mean of $\mathrm{P}_{\mathrm{T}}$ during both tested position resulting from the increase in ANS activity. A dynamics of parameter $\mathrm{P}_{\mathrm{HF}}$ which purely reflects vagal activity (Malik, 1995) shows that vagal activity increased in lying, but remained unchanged in supine position. Therefore an increase in $\mathrm{P}_{\mathrm{T}}$ was mainly induced by rising of spectral power in slow fluctuations area $\left(\mathrm{P}_{\mathrm{VLF}}\right.$ and $\left.\mathrm{P}_{\mathrm{LF}}\right)$ which is under influence either of both branches of ANS (Task Force, 1996) or mostly by sympathetic activity (Malliani, Pagani, Lombardi, \& Cerruti, 1991). Significant elevation of ratio $\mathrm{P}_{\mathrm{VLF}} / \mathrm{P}_{\mathrm{HF}}$ and $\mathrm{P}_{\mathrm{LF}} / \mathrm{P}_{\mathrm{HF}}$ during subsequent periods of convalescence could be sign of relative increase in sympathetic activity despite persisted prevailing vagal activity in autonomic cardiac regulation during supine. These changes in autonomic regulation results from the continuously rising training load among periods when the last period was classified as the most intensive. In addition, in this period was investigated significant growth in perceived fatigue. In this context Furlan et al. (1993) reported that trained athletes during peak intensity training showed a resting bradycardia together with high LF values, thus suggesting a more complex neural interaction modulating HR. We suppose that mentioned changes in ANS activity in well trained athlete could be classified positively, because a short recovery will follow by withdrawal of elevated sympathetic activity accompanied with the increase in vagal activity.
Our results further show non-significant changes in index of SA HRV between particular convalescence periods which means only small complex changes in ANS activity. Stejskal, Šlachta, Elfmark, Salinger, and Gaul-Aláčová (2002) supposed that complex index of SA HRV are more sensitive for assessment of discrete changes ANS activity than individual spectral variables, because these indexes includes all age-dependent individual spectral parameters which were sampled in both standing, and supine position. A well-balanced state of ANS was reached via optimization of training load when each negative change in index of SA HRV was followed by the reduction in training load or temporally interruption of training process. On the contrary, positive course of these indexes facilitated a more intensive training, and thereby an enhancement in physical fitness.

Noffsinger (1996) recommended that athletes for first few days of convalescence after IM should listen his or her body, and increase physical activities according to toleration. However, from the performed correlation analysis between ANS activity and morning fatigue in our study, it is evident that an athlete based on his subjective feelings is not able to assess his actual adaptation capacity. Nevertheless, the level of actual adaptation capacities plays an important role in adequate training load determination. Therefore, we inclined to opinion that self-perception of fatigue could be use as a tool for training load determination only in the few first days of convalescence after long lasting disease. However, longterm determination of the training load based on feeling of fatigue could be in this sense a misguided.

An investigation of functional state or size of liver and spleen could be helpful in determination of time frame of the return to play (Putukian et al., 2008; Waninger \& Harcke, 2005). In our study, we investigated a border line or mild elevated values of ALT (AST only in one measurement) while liver and spleen had, according to a medical report normal size. From review of Waninger and Harcke (2005) results that there has been no definitive correlation identified between an increase in of the spleen and blood liver/enzyme parameters, and further, no data support the use of serial hematological studies as an indicator of safety return to play. Therefore, we suppose that in given case the dynamics of liver enzymes did not indicate an excessive increase in training load during convalescence periods. 
In our study we further found successive decline in HR in supine and mostly in orthostatic stimulation. It is evident that this HR dynamics could be considered as a sign of new adaptation development. Because, two months of training interruption caused detraining which is associated with the partial or complete loss of training-induced anatomical, physiological and performance adaptations (Mujika \& Padila, 2001). From dynamics of HR is evident that a time course of cardiovascular adaptation could be controlled both in supine, and during orthostatic stimulation.

\section{Limitations}

An absence of control patient group together with only case study report could be considered the main limitation of this study. More research in this field is needed.

\section{CONCLUSIONS}

Our study shows that convalescence strategy based on assessment of ANS activity contributed an improvement in physical fitness, in spite of borderline or mild elevated transaminase level. Probably training guided by subjective feeling of fatigue within convalescence after IM could be inaccurate. In conclusion, we suggest that combination of both non-invasive SA HRV method and periodical assessment of biochemical indicators of liver state seems to be a promising strategy for determination of safe application of the training load during convalescence after IM. Finally, SA HRV can be accepted as an auxiliary method in infectious hepatitis patients with borderline biochemical parameters.

\section{ACKNOWLEDGEMENTS}

The study has been supported by the research grant from the Ministry of Education, Youth and Sports of the Czech Republic (No. MSM 6198959221) "Physical Activity and Inactivity of the Inhabitants of the Czech Republic in the Context of Behavioral Changes”.

\section{REFERENCES}

Aubert, A. E., Seps, B., \& Beckers, F. (2003). Heart rate variability in athletes. Sports Medicine, 33(12), 889-919.

Candy, B., Chalder, T., Cleare, A. J., Wessely, S., \& Hotopf, M. (2005). What advice do patients with infectious mononucleosis report being given by their general practitioner? Journal of Psychosomatic Research, 58(5), 435-437.
Furlan, R., Piazza, S., Dell'Orto, S., Gentile, E., Cerutti, S., Pagani, M., \& Malliani, A. (1993). Early and late effects of exercise and athletic training on neural mechanisms controlling heart rate. Cardiovascular Research, 27(3), 482-488.

Katz, B. Z., Shiraishi, Y., Mears, C. J., Binns, H. J., \& Taylor, R. (2009). Chronic fatigue syndrome after infectious mononucleosis in adolescents. Pediatrics, 124(1), 189-193.

Malik, M. (1995). Geometrical methods for heart rate variability assessment. In M. Malik \& J. Camm (Eds.), Heart rate variability (pp. 47-61). New York, NY: Futura.

Malliani, L., Pagani, M., Lombardi, F., \& Cerutti, S. (1991). Cardiovascular neural regulation explored in the frequency domain. Circulation, 84(2), 482-492.

Moolenar, W., Peters, W. G., \& Bolk, J. H. (1988). Fever, lymphadenopathy and shock in a 16 year old girl. Netherlands Journal of Medicine, 33(1-2), 37-40.

Mujika, I., \& Padilla, S. (2001). Muscular characteristics of detraining in humans. Medicine Science in Sports Exercise, 33(8), 1297-1303.

Noffsinger, J. (1996). Physical activity considerations in children and adolescents with viral infections. Pediatrics Annals, 25(10), 585-589.

Papesch, M., \& Watkins, R. (2001). Epstein-Barr virus infectious mononucleosis. Clinical Otolaryngology and allied Science, 26(1), 3-8.

Pařízková, J. (1998). Složení těla, metody měření a využití ve výzkumu a lékařské praxi. Medicina Sportiva Bohemica \& Slovaca, 7, 1-6.

Pichot, V., Busso, T., Roche, F., Garet, M., Costes, F., Duverney, D., Lacour, J. R., \& Barthelemy, J. C. (2002). Autonomic adaptations to intensive and overload training periods: A laboratory study. Medicine and Science in Sports and Exercise, 34(10), 1660-1666.

Putukian, M., O’Connor, F. G., Stricker, P., McGrew, C., Hosey, R. G., Gordon, S. M., Kinderknecht, J., Kriss, V., \& Landry, G. (2008). Mononucleosis and athletic participation: An evidence-based subject review. Clinical Journal of Sports Medicine, 18(4), 309-315.

Rea, T. D., Russo, J. E., Katon, W., Ashley, R. L., \& Buchwald, D. S. (2001). Prospective study of the natural history of infectious mononucleosis caused by Epstein-Barr virus. Journal of American Board of Family Practice, 14(4), 234-242.

Salinger, J., Opavský, J., Stejskal, P., Vychodil, R., Olšák, S., \& Janura, M. (1998). The evaluation of heart rate variability in physical exercise by using the telemetric variapulse TF3 system. Acta Universitatis Palackianae Olomucensis. Gymnica, 28, 13-23.

Salinger, J., \& Gwozdziewicz, M. (2008). Systémy používané pro vyšetření krátkodobé variability srdeční 
frekvence. In K. Javorka et al. (Eds.), Variabilita frekvencie srdca: Mechanismy, hodnotenie, klinické využitie (pp. 57-60). Martin: OSVETA.

Stejskal, P., Jakubec, A., Přikryl, P., \& Salinger, J. (2004). Vliv osmihodinového časového posunu po přeletu přes poledníky na východ na spektrální analýzu variability srdeční frekvence u špičkového sportovce (kasuistika). Medicina Sportiva Bohemica et Slovaca, 13(1), 2-10.

Stejskal, P., Šlachta, R., Elfmark, M., Salinger, J., \& Gaul-Aláčová, P. (2002). Spectral analysis of heart rate variability: New evaluation method. Acta Universitatis Palackianae Olomucensis. Gymnica, 32(2), 13-18.

Šlachta, R., Stejskal, P., \& Elfmark, M. (2003). Spektrální analýza variability srdeční frekvence u sportovců a modifikace tréninku pomocí spektrální analýzy. In J. Salinger (Ed.), Variabilita srdeční frekvence a jeji hodnocenív biomedicinských oborech - od teorie ke klinické praxi (pp. 134-139). Olomouc: Univerzita Palackého.

Task Force of the European Society of Cardiology and the North American Society of Pacing and Electrophysiology. (1996). Heart rate variability. Standards of measurement, physiological interpretation, and clinical use. Special report. Circulation, 93(5), 1043-1065.

Welch, M. J., \& Wheeler, L. (1986). Aerobic capacity after contracting infectious mononucleosis. Journal of Orthopeadic and Sports Physical Therapy, 8(4), 199-202.

Waninger, K. N., \& Harcke, H. T. (2005). Determination of safe return to play for athletes recovering from infectious mononucleosis: A review of the literature. Clinical Journal of Sports Medicine, 15(6), 410-416.

Wyller, V. B., Barbieri, R., Thaulow, E., \& Saul, J. P. (2008). Enhanced vagal withdrawal during mild orthostatic stress in adolescents with chronic fatigue. Annals of Noninvasive Electrocardiology, 13(1), 67-73.

Yamamoto, Y., \& Hughson, R. L. (1991). Coarse graining spectral analysis: New method for studying heart rate variability. Journal of Applied Physiology, 71(3), 1143-1150.

\section{REKONVALESCENCE PO INFEKČNÍ MONONUKLEÓZE ŘÍZENÁ NA ZÁKLADĚ AKTIVITY AUTONOMNÍHO NERVOVÉHO SYSTÉMU U VRCHOLOVÉHO SPORTOVCE: KAZUISTIKA}

(Souhrn anglického textu)

VÝCHODISKA: Infekční mononukleóza (InM) je závažné onemocnění vyvolané Epstein-Barr virem, které vyžaduje okamžité přerušení tréninku.

CÍLE: Hlavním cílem naší práce bylo vytvořit optimální rekondiční program pro vrcholového sportovce po recidivě InM, který povede $\mathrm{k}$ jeho bezpečnému návratu do vrcholového sportu.

METODIKA: Ř́zená rekonvalescence trvala téměř tři měsíce. Dávkování zatížení bylo podřízeno aktuální úrovni aktivity autonomního nervového systému (ANS), která byla opakovaně diagnostikována metodou spektrální analýzy variability srdeční frekvence (SA VSF). Hodnoceny byly individuální parametry - spektrální výkon v oblasti velmi nízké frekvence $\left(\mathrm{P}_{\mathrm{VLF}}\right)(0,02-0,05 \mathrm{~Hz})$; výkon v oblasti nízké frekvence $\left(\mathrm{P}_{\mathrm{LF}}\right)(0,05-0,15 \mathrm{~Hz})$; výkon v oblasti vysoké frekvence $\left(\mathrm{P}_{\mathrm{HF}}\right)(0,15-0,50 \mathrm{~Hz})$; celkový spektrální výkon $\left(\mathrm{P}_{\mathrm{T}}\right)(0,02-0,50 \mathrm{~Hz})$; poměry $\mathrm{P}_{\mathrm{VLF}} / \mathrm{P}_{\mathrm{HF}}$ a $\mathrm{P}_{\mathrm{LF}} / \mathrm{P}_{\mathrm{HF}}$ a srdeční frekvence (SF). Dále byla aktivita ANS posuzována pomocí komplexních indexů SA HRV - indexu vagové aktivity, sympatovagové balance a celkového skóre. $\mathrm{V}$ práci bylo hodnoceno i subjektivní vnímání zatížení společně s ranní únavou. Prováděny byly také biochemické analýzy aktivity vybraných jaterních enzymů.

VÝSLEDKY: Během rekonvalescence došlo ke zvýšení průměrné hodnoty $\mathrm{P}_{\mathrm{T}}$, které doprovázelo zvýšení poměru $\mathrm{P}_{\mathrm{VLF}} / \mathrm{P}_{\mathrm{HF}}$ a $\mathrm{P}_{\mathrm{LF}} / \mathrm{P}_{\mathrm{HF}}$. Mezi jednotlivými etapami rekonvalescence nedošlo $\mathrm{k}$ signifikantním změnám u žádného z komplexních indexů SA HRV. V lehu a především ve stoji byl zaznamenán signifikantní pokles SF. Dále byl během rekonvalescence pozorován signifikantní vzestup subjektivně vnímaného zatížení a v poslední etapě došlo ke kulminaci ranní únavy. Mezi komplexními indexy SA HRV a pocitem ranní únavy nebyl prokázán žádný vztah.

ZÁVĚRY: Rekonvalescence řízená na základě monitoringu aktivity ANS přispěla ke zlepšení kondice, přestože aktivita jaterních enzymů zůstávala hraniční až mírně zvýšená. Dávkování zatížení založené na subjektivním hodnocení únavy v rámci rekonvalescence po InM bude pravděpodobně nepřesné. Proto se domníváme, že neinvazivní metoda SA VSF společně s pravidelnou biochemickou analýzou jaterních enzymů se zdá být slibnou strategií pro stanovení bezpečného zatížení během rekonvalescence po InM, která povede $\mathrm{k}$ návratu sportovce do plného zatížení.

Klícová slova: variabilita srdeční frekvence, únava, hepatitida, Epstein-Barr virus, detrénink, rekonvalescence. 


\section{PhDr. Michal Botek, Ph.D.}

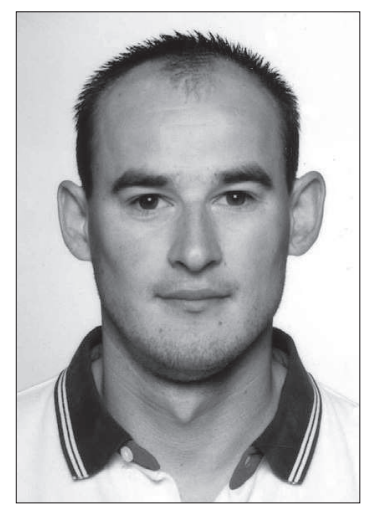

Palacký University, Olomouc Faculty of Physical Culture tř. Míru 115 77111 Olomouc Czech Republic

\section{Education and previous work experience}

Since 2007 - Institute of Active Lifestyle (Center of Kinanthropology Research), Faculty of Physical Culture, Palacký University, Olomouc.

2008 - Doctoral degree - PhDr. (Philosophy), Faculty of Physical Culture, Palacký University, Olomouc.

2007 - Doctoral degree - Ph.D. (Kinanthropology), Faculty of Physical Culture, Palacký University, Olomouc. 2003 - Master's degree - Mgr. (Physical Education and Geography), Faculty of Physical Culture, Palacký University, Olomouc.

\section{Scientific orientation}

Exercise physiology and its application into the sport events, main research objects: assessment of autonomic nervous system activity by spectral analysis of heart rate variability and its using in various areas for instance: simulated altitude; training dose optimalization; talent identification in sport; quantification of fatigue; jet lag syndrome problematic and/or vagal threshold determination.

\section{First-line publications}

Botek, M., Stejskal, P., Krejčí, J., Jakubec, A., \& Gába, A. (2010). Vagal threshold determination. Effect of age and gender. International Journal of Sports Medicine, 31(11), 768-772.

Botek, M., Stejskal, P., \& Klimešová I. (2010). Vliv barické hypoxie na aktivitu autonomního nervového systému: pilotní studie. Medicina sportiva Bohemica et Slovaca, 19(4), 191-195.

Botek, M., Stejskal, P., \& Svozil, Z. (2009). Autonomous nervous system activity during acclimatization after rapid air travel across time zones: A case study. Acta Universitatis Palackianae Olomucensis. Gymnica, 39(2), 13-21.

Botek, M., Stejskal, P., \& Neuls, F. (2008). Monitoring of the autonomic nervous system activity during post-marathon recovery by spectral analysis of heart rate variability: A case study. Medicina Sportiva, 12(2), 31-35. 